\section{Promotion of the Environmental Knowledge and Behavior through the Moroccan Syllabus of Sciences in the Middle School}

\author{
Bouchta El Batria, Anouar Alami b, ${ }^{*}$, Moncef Zakic, Youssef Nafidid, \\ Driss Chenfoure
}

$\begin{array}{ll}\text { Received: } & \text { 6 July } 2018 \\ \text { Revised: } \quad & 11 \text { December } 2018 \\ \text { Accepted: } \quad & 5 \text { February } 2019 \\ \text { ISSN: } 1307-9298 \\ \text { Copyright } \odot \text { IEJEE } \\ \text { www.iejee.com }\end{array}$

DOI: $10.26822 /$ iejee.2019450795

\begin{abstract}
This research paper aims to promote environmental knowledge and behavior in the Moroccan school through the syllabus of science at the level of the Moroccan middle School. As a first step, a comparative multi-case study was conducted. It is intended for students from four middle Schools who belong to four different socio-environmental backgrounds. The survey was conducted through questionnaires which consist of four sections; the learning methods, the teaching aids, environmental knowledge, and the use of environmental knowledge in adequate eco-responsible behaviors. Based on the analysis of the results obtained at the level of the four schools, a teaching intervention of four weeks ( 2 hours per week) was then carried out. During this process, the same program was taught but otherwise. In order to meet the objectives of this work, we have inserted some local environmental problems through active learning methods and relatively appropriate teaching aids. In our intervention, we have made the necessary link between ecological knowledge and the appropriate pro-environmental behavior. This, however, is attributed to the fact that it has never been used before. The results show that there is a significant improvement, both in terms of environmental knowledge acquired and the intentions to adopt eco-friendly environmental behaviors.
\end{abstract}

Keywords: Environmental Knowledge, Environmental Behavior, Middle School, Active Learning, Local Environment

\section{Introduction}

The future of societies and their development are very closely related to their relationship to the environment (Declaration, 1992). This relationship is the subject of any environmental education (EE). According to several authors, education is the key element in the prevention and resolution of environmental problems (Makki, Abd-El-Khalick, \& BouJaoude, 2003; Tuncer, Ertepinar, Tekkaya, \& Sungur, 2005).

According to studies conducted in Turkey (Özdem, Dal, Öztürk, Sönmez, \& Alper, 2014; Tuncer, Sungur, Tekkaya, \& Ertepinar, 2007), middle school students stated that school is among the main sources of information in regards to various environmental problems (climate change) (cited by Higde, Oztekin, \& Sahin, 2017). Also, (Erten, 2005; Karataş, 2011; Keles, Uzun, \& Varnaci- Uzun, 2010; Miser, 2010; Samur, 2018) argued that nature education programs have a significant impact on individual environmental awareness, attitudes, and behaviors. Esa (2010) emphasized that teachers are the most influential ones in educating children and adolescents to become tomorrow's leaders in environmental advocacy. However, the knowledge and skills of teachers (Akçalı \& Demircioğlu, 2017), the choice of teaching methods (Mikerova, Sergeeva, Mardirosova, Kazantseva, \& Karpenko, 2018) and teaching aids (Acar, Tertemiz, \& Taşdemir, 2018) significantly influence the quality of learning.

Regarding learning methods, active learning is generally defined as any teaching method that "engages students in the learning process" (Bonwell \& Eison, 1991, p. 5; Collins \& O'Brien, 2011, p. 23). This type of learning requires students to engage in meaningful learning activities and reflect on what they are doing. This is the opposite of traditional methods centered on the transmission of the same content and passivity of students (dogmatic method, interrogation-response method). The key element of active learning is the active involvement of the learner (VanWinkle, Davis, \& Larwood 2002). Consequently, active learning exists based on the recommendations of Felder, Woods, Stice and Rugarcia (2000). It is also one of the "seven principles of good practice" by Chickering and Gamson (1987). However, under the active learning label, there are different teaching methods that are best evaluated separately (Prince, 2004).

Active learning methods have been widely studied and recognized to have a positive significant effect on student outcomes including working in small groups (D. W. Johnson, Johnson, \& Smith, 1998; Norman \& Schmidt, 2000; Silberman, 1996; and others), collaborative learning (Felder et al., 2000; Johnson et al., 1998; Prince, 2004), the problem-solving method (Bonwell \& Eison, 1991; Norman \& Schmidt, 2000). Problem-based learning is often associated with another active method which is learning through discovery (Goldberg \& Nagurka, 2012; Mayer, 2004; Prince \& Felder, 2006). Discovery learning can be defined as "An instructional approach that encourages students to learn through their own exploration, experience, and inquiry. Learning typically proceeds from identification of a problem, through development, and testing of hypotheses, to drawing a conclusion" (Collins \& O'Brien, 2011, p. 160). In this process, the teacher is "a facilitator rather than an instructor, and it is their role to organize a rich or appropriately resourced learning environment and to encourage the learner's self-directed curiosity and prob-

\footnotetext{
* Corresponding Author: Anouar Alami, Interdisciplinary Research Laboratory in Didactics of Science and Technology, LIRDIST, Faculty of Sciences Dhar Mahraz, Sidi Mohamed Ben Abdellah University, Fes, Morocco. E-mail:anouar.alami@usmba.ac.ma

aBouchta El Batri, Interdisciplinary Research Laboratory in Didactics of Science and Technology, LIRDIST, Faculty of Sciences Dhar Mahraz, Sidi Mohamed Ben Abdellah University, Fes, Morocco.

cMoncef Zaki, Interdisciplinary Research Laboratory in Didactics of Science and Technology, LIRDIST, Faculty of Sciences Dhar Mahraz, Sidi Mohamed Ben Abdellah University, Fes, Morocco.

youssef Nafidi, Interdisciplinary Research Laboratory in Didactics of Science and Technology, LIRDIST, Faculty of Sciences Dhar Mahraz, Sidi Mohamed Ben Abdellah University, Fes, Morocco.

eDriss Chenfour, Oum Lbanin High school, Fez Morocco.
} 
lem-solving skills, rather than to demonstrate or provide 'correct' answers or procedures" (Wallace, 2015). Furthermore, other active learning methods can be found such as dialogue method (Alexander, 2001, 2006; Do, 2003; Muhonen, Rasku- Puttonen, Pakarinen, Poikkeus, \& Lerkkanen, 2016). It is introduced by Paulo Freire, in which teachers engage learners in discussion to understand their perceptions and experiences (Collins \& O'Brien, 2011). Dialogic teaching harnesses "The power of talking to stimulate and develop students' thinking, learning and understanding" (Alexander, 2001). Dialogic interactions are defined as "exchanges where students ask questions, explain their points of views and make comments about each other's ideas. The crux of dialogue is to exchange ideas that prompt further questions" (Alexander, 2006; Quoted by Muhonen et al., 2016).

The "demonstrative method" (Ameh, Daniel, \& Akus, 2007; Ekeyi, 2013; Kresta, 1998) refers to the type of teaching method in which:

The teacher is the principal actor while the learners watch with the intention to act later. Here the teacher does whatever the learners are expected to do at the end of the lesson by showing them how to do it and explaining the step-by-step process to them. (Quoted by Ekeyi, 2013, p. 2).

In the end, active learning can include other methods such as experiential learning (Karpudewan \& Mohd Ali Khan, 2017), and the project-based learning method (Bordallo \& Ginestet, 2006; Hartmann, Näf, \& Reichert, 2011; Huber, 2005).

Consequently, the field of EE is largely influenced by active learning methods, which was the reason we found more or less the same methods recommended in EE. This aims to improve knowledge, values, attitudes, and behaviors towards the environment. Genc $(2015$, p.2) states that active learning methods must be implemented to achieve effective EE. Leeming, Porter, Dwyer, Cobern and Oliver (1997) and Cheong (2005) reported that teaching methods that encourage more active student engagement helps in improving students' environmental attitudes and conceptual understanding.

In addition to the methods already mentioned, studies in EE have stressed the importance of visits and field trips cognitively, emotionally, physically, and morally (Ballantyne \& Packer, 2005; Dori \& Tal, 2000; Saribas, Kucuk, \& Ertepinar, 2017, p. 9).

Active and effective learning requires the use of several teaching aids (Asokhia, 2009; Unesco, 2016, p. 215). Many studies have shown the importance of each of the teaching aids in improving learning as well as the factors influencing its use. Among the teaching aids used in sciences, and which are solicited by several authors, we noted the ICTE (Nafidil, Alami, Zaki, El Batri \& Afkar, 2018; Norton, McRobbie, \& Cooper, 2000; Sangra \& González-Sanmamed, 2011; Wendt, Rockinson-Szapkiw \& Cordes,2018) and the lab experiments (Aglan \& Ali, 1996; Falk \& Heckman, 2009). On the other hand, the excessive use of the textbook has provoked several criticisms (Adebayo \& Adigun, 2018; Rodríguez \& Paiva,2017). Asokhia (2009) linked the poor performance of students to the dominance of textbooks as the only teaching aid.

\section{Research Questions}

Based on this perspective, the study answers three research questions:

1. To what extent are the learning methods and teaching aids used in a science course as a good indicator of effective learning?
2. How do we effectively use some teaching aids such as images to help students acquire environmental knowledge (eg food chains) so as to improve their environmental behavior?

3. Is there a positive correlation between integrating local environmental issues into an ecological course of science and improving the acquisition of knowledge and increasing motivation to adopt pro-environmental behaviors?

\section{Methodology}

\section{Research Design}

Indeed, the choice of the studied institutions were oriented to reflect the main socio-economic cases whereby the student lives in Morocco. The study concerns four middle Schools; Two public middle schools in precarious environments, one rural and the other urban, and two other institutions belonging to a neighborhood of the middle and upper class, one private and the other public.

Intervention was administered to 3 experimental groups of first-year middle school students. The lessons were taken from the units of the official syllabus of the sciences of this same grade level (Directorate of Curricula, 2009).

A quasi-experimental design that is often used to evaluate the effectiveness of a treatment or an educational intervention due to the lack of random assignment (Falk \& Heckman, 2009; Shadish, Cook, \& Campbell, 2002). This design has been used as it is considered by several methodologists to be the most appropriate for studying the effectiveness of intervention in intact environments (Falk \& Heckman, 2009; Shadish, Cook, \& Campbell, 2002). Indeed, we cannot perfectly control all the variables that come across the teaching-learning situation and among other the initial characteristics of the groups studied. For this reason, the use of several control and experimental groups seems necessary. Thus, a lot of recent studies have used this same design in similar conditions (Fröhlich, Sellmann, \& Bogner, 2013; Gottlieba, Vigoda- Gadota, \& Haim, 2013; Karpudewan, Roth, \& Abdullah, 2015; Karpudewan \& Mohd Ali Khan, 2017).

\section{Samples}

Samples of the comparative study. From a population of 633 students from 4 different middle Schools, an exhaustive sample of 400 students (100 students per institution) was taken. We used the cluster sampling method because we have taken four middle schools that represent four different socioeconomic groups to which a Moroccan student can belong. All students, subject of the study, continue their studies in first year middle School. The sample studied comprises of 198 boys and 202 girls. For the three public middle school studied, we have about 40 students per class. On the other hand, the number of students does not exceed 27 for the private school. Among the three levels of middle school, the first-year program (object of study) contains the most important content related to the environment and can be exploited in the sense of environmental education.

Samples of the experimentation (the intervention) and the control. The experiment was carried out at the level of the public urban middle school of precarious environment that has low scores in terms of students' performance. For the three experimental samples, they consist of 61 volunteer pupils; 39 girls and 22 boys (Table 1). An experimental group of 21 students was treated in January-February 2017 and two other groups (20 students each) were treated in October-November 2017. For the 3 control groups, the same sample of the comparative study was used, ( 100 students with 45 boys and 55 girls) belonging to the same school (urban public of precarious environment). 


\section{Data Collection Tool}

Data was collected using a four-component questionnaires that are as follows: an assessment of the learning methods used (10 items), teaching aids ( 6 items), environmental knowledge (5 items), and the use of environmental knowledge in eco-responsible behaviors (3 items). Items concerning the learning methods and teaching aids used were administered only to the comparative study samples (consists of 400 students). The items related to environmental knowledge were administered to all the samples studied (461 students), using the results of 100 students belonging to the precarious public school (comparative study) as a control for the results of the intervention carried out with other groups (61 students) from the same school (Table 8). The items concerning eco-responsible behaviors were reserved only for the three groups of the intervention (61 students).

Table 1. Control and experimental sample for the intervention

\begin{tabular}{ccccc}
\hline & Groups & $n 1$ (boys) & $n 2$ (girls) & Tot \\
\hline \multirow{3}{*}{$\begin{array}{c}\text { Control sample } \\
\text { (Regular sessions) }\end{array}$} & Gr1 & 20 & 20 & 40 \\
\cline { 2 - 5 } & Gr2 & 17 & 23 & 40 \\
\cline { 2 - 5 } & Gr3 & 8 & 12 & 20 \\
\hline \multirow{3}{*}{$\begin{array}{c}\text { Experimental } \\
\text { sample } \\
\text { (intervention) }\end{array}$} & Tot & 45 & 55 & 100 \\
\cline { 2 - 5 } & Gr1 & 7 & 14 & 21 \\
\cline { 2 - 5 } & Gr3 & 6 & 14 & 20 \\
\hline
\end{tabular}

The items of the questionnaire have been reformulated several times, in collaboration with the research committee. This was done to ensure its reliability, clarity, and preciseness. The penultimate version of the questionnaire was tested beforehand with a group of 15 students. These students all belong to the same grade level as the experimental groups. The questions posed by these students, as well as their response, allowed us, once again, to rephrase some questions before reaching the final version of the questionnaire. The reliability index (Cronbach's alpha) applied to each component of the questionnaire gave the following values: 0.698 for learning methods, 0.687 for teaching aids and 0.764 for environmental knowledge, indicating that the internal consistency of the questionnaire is satisfactory.

Regarding the validity of the content of the questionnaire, the knowledge test questions are accurate and representative of all units of the environmental science program that are likely to be exploited in environmental education. This is what was done in the section on "the use of environmental knowledge in eco-responsible behavior". With regard to learning methods and teaching aids, in addition to our experience as science teachers, we have carefully explored the literature to identify the different learning methods and teaching aids that can be used in a science course. The responses collected giving a very low proportion to the section "other methods" and "other teaching aids" show that the main methods of learning and teaching aids are actually the ones we used. That constitutes an element of the validity of the contents of the questionnaire. Also, the discriminative power of the instrument was tested a second time one month after the data collection of the comparative study. This test was carried out at the level of the public urban middle school of the precarious environment and the private middle school. The results similar to those found during the first data collection were representing $90 \%$. That is to say, there is still a significant predominance of private school, especially in terms of the active methods used and the diversification of teaching aids administered.

The questionnaire also benefited from the external validity provided by the latest report of the Higher Council for Education, Training and Scientific Research (Rapport CSEFRS, 2018) entitled "A School of Social Justice", of which the main focus was shed on educational inequalities between urban and rural areas on the one hand and between public and private schools on the other.

\section{Data Collection}

Learning methods, teaching aids and eco-responsible behaviors. We explored the different methods that can be used in a science course. In general, there are two families of learning methods: traditional (or dogmatic) methods and active methods (Arénilla, Gossot, Rolland, \& Roussel, 2009, p. 194). The traditional methods tested are the lecture method (Dufresne, Gerace, Leonard, Mestre, \& Wenk, 1996) and the interrogation-response method (Arénilla et al., 2009). For active methods that require active involvement of the learner, we proposed active dialogue, group work, demonstrative method, discovery method, field trips, and students' presentations and experimentations.

To find out what methods were used in each institution, we presented simple and clear definitions of each method (Table 2). However, we chose to propose them to 100 students from each institution instead of one teacher or two of the sciences that exist in each of these institutions.

To measure the frequency of the use of each learning method as well as teaching aids, the 5-point Likert scale was used; 0 point was awarded to "I do not know", 1 point to "not used", 2 to "rarely", 3 to "occasionally", and 4 to "often". Furthermore, Furthermore, this same scale was used to measure students' intentions (from the intervention sample) to use the knowledge (learned during the intervention sessions) in their daily lives and particularly in three areas: the economy in the use of water, the preservation of the near environment against pollution, and the preservation of the forest against fires.

\section{Table2. Examples of proposed learning methods}

(1) The teacher explains the lesson and the students listen without participation (dogmatic).

(2) Partial participation of students by answering some ques-

tions asked by the teacher. (Interrogation-response method)

(3) Dialogue method with active participation of students at all stages of the lesson.

(4) Group work method for performing works and assignments either inside or outside the classroom.

(5) Realization of laboratory experiments.

(6) Performing school outings to supplement and support environmental knowledge.

The diversification of learning sequences, as well as the use of a wide range of learning supports, constitutes effective teaching strategies (Asokhia, 2009; UNESCO, 2016, p. 214). To evaluate the diversification of teaching aids used, we measured the degree of the use of each of the following teaching aids: the textbook, Documents presented by the teacher, audio-visual and ICT, lab tools and samples.

Environmental knowledge test. The environmental knowledge test is taken from the official syllabus of the sciences of the first middle school year of Morocco (Directorate of Curricula, 2009). The themes in question are food chains and networks, factors of natural imbalances, components of the cell as a structural unit of the living being, and risks to water resources. Five specific questions have been se- 
lected, all of which are part of the objectives of this syllabus. 2 points for each correct answer, 0 point for each false answer, and 1 point for each incomplete answer. For example, for the fifth question: Name 2 human-caused risks that threaten water resources. Students who cited a single risk had a single point. Students with an average grade of $5 / 10$ or higher were counted. Thus, the test questions are as follows:

Table 3. Environmental Knowledge Test Quesitons

\begin{tabular}{|c|c|c|}
\hline \multicolumn{3}{|c|}{ (1) Write correctly an example of a food chain. } \\
\hline \multicolumn{3}{|c|}{$\begin{array}{l}\text { (2) What are the living things by which food chains usually start } \\
\text { (the first link)? }\end{array}$} \\
\hline \multicolumn{3}{|c|}{$\begin{array}{l}\text { (3) Name three factors which are responsible for natural imbal- } \\
\text { ances. }\end{array}$} \\
\hline \multicolumn{3}{|c|}{$\begin{array}{l}\text { (4) The cell is the structural unit of living beings. Name its main } \\
\text { constituents. }\end{array}$} \\
\hline \multicolumn{3}{|c|}{$\begin{array}{l}\text { (5) Name two human-related hazards that threaten water } \\
\text { resources. }\end{array}$} \\
\hline \multicolumn{3}{|c|}{ able 4. Units and objectives of the } \\
\hline Units & Objectives & Duration \\
\hline $\begin{array}{l}\text { 1. The cell, structural } \\
\text { unit of the living } \\
\text { being }\end{array}$ & $\begin{array}{l}\text { - Identify the cell as a } \\
\text { structural unit of the living } \\
\text { being and discover its main } \\
\text { components: the nucleus, } \\
\text { the cytoplasm, and the cyto- } \\
\text { plasmic membrane. }\end{array}$ & $2 \mathrm{~h}$ \\
\hline $\begin{array}{l}\text { 2. Chains and food } \\
\text { webs }\end{array}$ & $\begin{array}{c}\text { - Observation and analysis } \\
\text { of food relations in a natural } \\
\text { environment to discover the } \\
\text { concepts of food chains and } \\
\text { networks. }\end{array}$ & $2 \mathrm{~h}$ \\
\hline $\begin{array}{l}\text { 3. The natural } \\
\text { balances }\end{array}$ & $\begin{array}{l}\text { - Identify aspects of a } \\
\text { balanced environment and } \\
\text { discover the factors causing } \\
\text { natural imbalances. } \\
\text { - Deduce behaviors that } \\
\text { contribute to maintaining the } \\
\text { ecological balance. }\end{array}$ & $2 \mathrm{~h}$ \\
\hline $\begin{array}{l}\text { 4. Risks threatening } \\
\text { water resources }\end{array}$ & $\begin{array}{l}\text { - Identify the main threats to } \\
\text { water resources and some of } \\
\text { their consequences. } \\
\text { - Deduce the eco-responsible } \\
\text { behaviors towards the water. }\end{array}$ & $2 \mathrm{~h}$ \\
\hline
\end{tabular}

\section{Data Analysis}

It is a mixed research with qualitative phases and quantitative phases. The qualitative phase is manifested in the study of four particular cases of school and taking into account several interrelated variables in a complex context (Sauvé, 1999, p. 13). These variables are student performance, learning methods, teaching aids, and number of students per class. Also this qualitative phase was used to extract the pro-environmental behaviors from a preliminary analysis of the syllabus of the sciences.

To compare the data of the 4 cases studied and the intervention, we used some of the quantitative methods. This is particularly the case of the descriptive statistics for the percentages of the values of each variable studied, the correlations between these variables and the variance Analysis Tests (ANOVA). The statistical measurements were performed using IBM SPSS20 statistical software.

\section{Results and Discussions}

\section{Learning methods}

Figure 1 shows a clear predominance of the private middle School regarding the use of different active methods (often or occasionally) such as the discovery method (92\%), laboratory experiments $(81 \%)$, demonstrative method (82\%),
ICT (81\%), active dialogue (77\%), teamwork (73\%), school outings (74\%), etc. Whereas the traditional dogmatic method was declared to be weakly used in this same private establishment (35\%). On the other hand, the same method (dogmatic) is more used in the three public schools studied (more than 50\%). School outings are very poorly used in all public middle Schools studied (8 to $29 \%$ ), while they are well represented at the private school level (74\%). The demonstrative method through the ICTE is also weakly used at the level of rural and urban public middle Schools of the precarious environment.

The calculation of the average of the percentages of the active methods used in each of the four establishments revealed a high application of these methods at the level of private school (77.5\%), a moderate application in the public middle School of the city centre (59.25\%), and a low use of these methods at the level of public rural and precarious schools ( $46.87 \%$ and $44.87 \%$ respectively).

Table 6 shows very significant correlations between the school variation and the variation in methods used. In fact, the methods that are used with very significant differences between the schools studied are active dialogue, discovery method, student presentations, demonstrative methods, laboratory experiments and School outings. These are all active methods associated primarily with private school and to a lesser extent with the school located in downtown. This is due to a considerable deficiency in the laboratory experience and environmental exits in this school. The dogmatic method is significantly correlated with the three public schools. It is also noted that the interrogative method is the only one that has not shown any significant difference in its use among the schools studied (Table 6).

The application of Spearman's correlation between the degree of use of the active methods and the results of the knowledge test confirmed the existence of a significant positive correlation between the administration of these active methods and the students' grades (the correlation coefficient is equal to 0.282 with a significance at the 0.01 level). This implies that the active methods are highly recommended to improve learners' achievement. On the contrary, dogmatic method is negatively correlated with the learner's outcome.

In the literature, there are several works testifying to the inescapable impact of active learning methods on the significant improvement of learning and academic performance (Bonwell \& Eison, 1991; Dufresne et al., 1996; Felder et al., 2000; Karpudewan \& Mohd Ali Khan, 2017; Prince, 2004; Silberman, 1996; VanWinkle et al., 2002). These methods put the learner at the core of the educational action through which he/she is offered means to become an active player in the learning process. According to the results obtained, the frequent use of active learning methods can be said to be an indicator of effective learning, especially when these methods are used with a staff of not more than 25 students.

\section{Teaching Aids}

Figure 2 shows that the most frequently used teaching aid in all public institutions studied is the textbook (between $62 \%$ and $69 \%$ ). However, in the private school, the textbook arrives exactly at the last position (13\%), i.e. it is substituted by other teaching aids, and in particular the documents prepared by the teacher $(83 \%)$, the ICT $(68 \%)$, the samples (52\%), and the laboratory tools. All these teaching aids are well represented quantitatively.

Table 7 shows very significant correlations between the schools studied and the teaching aids used. These correlations are, mainly, due to the very significant differences between the private school and the three public schools 
Table 5. Methods, learning activities and teaching aids

\begin{tabular}{|c|c|c|}
\hline Units & Objectives & Duration \\
\hline 1 & $\begin{array}{l}\text { - Experimental method and group work: Using a teacher's demonstration, the } \\
\text { students discovered the components of the light microscope, how it is used, and } \\
\text { the method of performing a microscopic preparation. } \\
\text { Working in groups ( } 4 \text { per group), students made microscopic preparations of } \\
\text { onion epithelium and oral epithelium; then they observed them by microscope } \\
\text { and they drew a cell of each of the two tissues. } \\
\text { Students compared the components of the two cell types to deduce the } 3 \text { main } \\
\text { components of a cell; the nucleus, the cytoplasmic membrane, and the cyto- } \\
\text { plasm. } \\
\text { By using computer images projected by data show, students observed other } \\
\text { animal and plant tissues to conclude that the cell is the structural unit of the living } \\
\text { being. } \\
\text { - Oral evaluation and recapitulation. }\end{array}$ & $\begin{array}{l}\text { - Optical microscopes } \\
\text { - Slide and cover slip } \\
\text { - Dyes (methylene blue } \\
\text { and neutral red) } \\
\text { • Onions } \\
\text { - Computer and } \\
\text { - Data show }\end{array}$ \\
\hline 2 & $\begin{array}{c}\text { - Demonstrative method: From the observation of the image of a natural environ- } \\
\text { ment, the students analyzed the food relations existing between the living beings } \\
\text { of this environment and, following the instructions (demonstration), they wrote } \\
\text { simple food chains correctly. } \\
\text { From the observation and analysis of several food chains, which students wrote } \\
\text { on the board, they deduced that: - Plants are the first link in all food chains. - } \\
\text { Existing food chains in an environment are linked and intertwined to form a food } \\
\text { web. } \\
\text { - Evaluation: From several series of images of anonymous and disorderly living } \\
\text { beings (multimedia resource), each student rearranges a series of images to build } \\
\text { a food chain. } \\
\text { - Oral recapitulation. }\end{array}$ & $\begin{array}{c}\cdot \text { Computer } \\
\text { - Data show } \\
\text { - Digital resources: im- } \\
\text { ages of natural environ- } \\
\text { ments, several series of } \\
\text { images of anonymous } \\
\text { and disordered living } \\
\text { beings to form food } \\
\text { chains }\end{array}$ \\
\hline
\end{tabular}

- Group work method and discovery: One week before this lesson, the students of the 3 experimental groups were asked to prepare research in groups of 3 people. Research is focused on natural balances and natural imbalance factors. After selecting the 2 best searches by class, the selected students exposed their research and at the same time, the others took notes according to a grid drawn on the board. The students filled the grid consisting of 3 columns: the aspects of a balanced environment, the factors of natural imbalance, and their consequences. Based on the observation of some shocking images relating to the factors of ecological imbalances (fire, pollution and overexploitation of natural resources), the students were invited to draw from each image the eco-responsible behaviours that contribute to maintaining the ecological balance. - Oral evaluation and recapitulation

- Student research -Images of natural environments and ecological imbalance

factors

- Computer

- Data show

- Discovery method: To discover the main risks threatening water resources, two local examples were used. The first concerns the pollution of the river "Sebou", the second example concerns the total drying of Lake "Dayet aoua" $(47.9 \mathrm{~km}$ south of the city of Fez).

Students are asked to interview their families (parents and grandparents) on 2 questions:

4 1- Identify the fish species that disappeared from the "Sebou" River and determine the causes of their extinction.

2- Identify the causes of the total drying of Lake "Dayet aoua".

The student responses were supported by images of the pollution of the river "Sebou" and images of the extirpated specie.

From the analysis of these 2 local examples, students deduced the need to adopt certain eco-responsible behaviors. - Evaluation and recapitulation.

\section{- Images of water pollution \\ -Pictures showing water wastage \\ -Image of the extinct \\ species (the Alose) \\ -Student research \\ - Computer \\ -Data show}

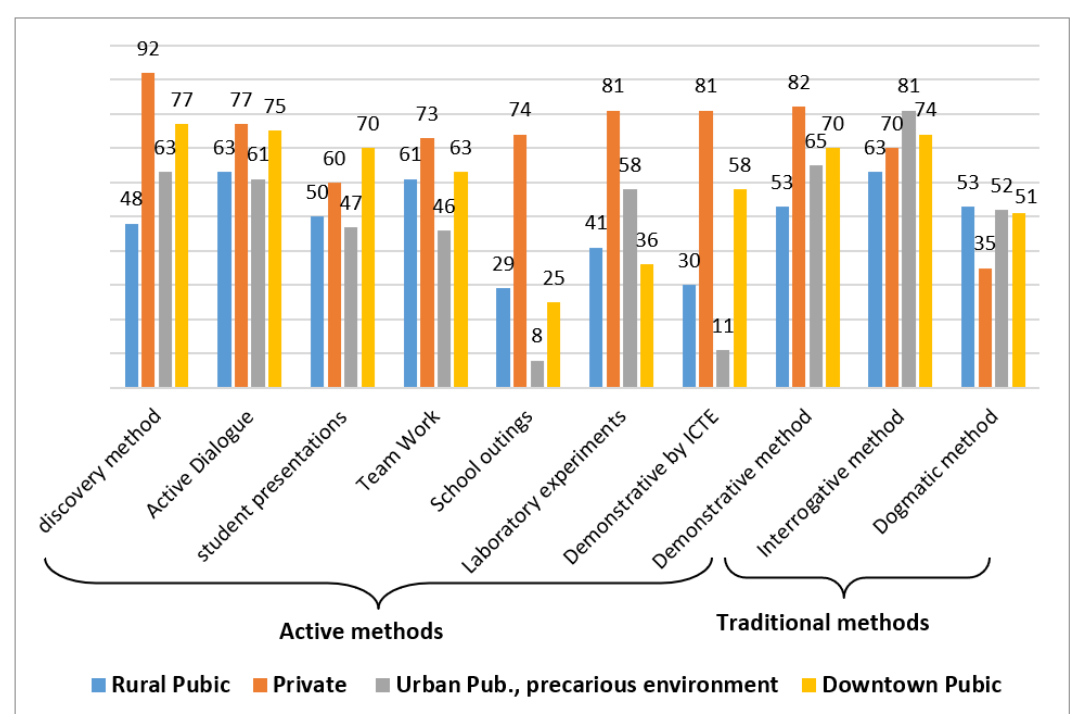

Figure 1. Percentage of use (often or occasionally) of the different methods in the four schools 
Table 6. Spearman's correlation between the school variation and the variation in methods used

\begin{tabular}{|c|c|c|c|c|c|c|c|c|c|c|c|}
\hline & & $\begin{array}{l}\text { Dogmatic } \\
\text { method }\end{array}$ & $\begin{array}{l}\text { Interrogative } \\
\text { method }\end{array}$ & $\begin{array}{c}\text { Active } \\
\text { Dialogue }\end{array}$ & $\begin{array}{l}\text { Team } \\
\text { Work }\end{array}$ & $\begin{array}{l}\text { Discovery } \\
\text { Method }\end{array}$ & $\begin{array}{c}\text { Student } \\
\text { Presentations }\end{array}$ & $\begin{array}{l}\text { Demonstrative } \\
\text { method }\end{array}$ & $\begin{array}{l}\text { Demonstra- } \\
\text { tive by ICTE }\end{array}$ & $\begin{array}{l}\text { Lab. } \\
\text { experiments }\end{array}$ & $\begin{array}{l}\text { School } \\
\text { outings }\end{array}$ \\
\hline \multirow{3}{*}{ Schools } & $\begin{array}{l}\text { Correlation } \\
\text { Coefficient }\end{array}$ & $-.122^{\star}$ & .062 & $.187 * \star$ & $.125^{*}$ & $.350 * *$ & $.154^{* *}$ & $.247^{* *}$ & $.477^{* *}$ & $.245^{\star *}$ & $.402^{* *}$ \\
\hline & $\begin{array}{c}\text { Sig. } \\
\text { (2-tailed) }\end{array}$ & .015 & .216 & .000 & .013 & .000 & .002 & .000 & .000 & .000 & .000 \\
\hline & $N$ & 400 & 400 & 400 & 400 & 400 & 400 & 400 & 400 & 400 & 400 \\
\hline
\end{tabular}

* Correlation is significant at the 0.05 level (2-tailed).
$* *$ Correlation is significant at the 0.01 level (2-tailed).

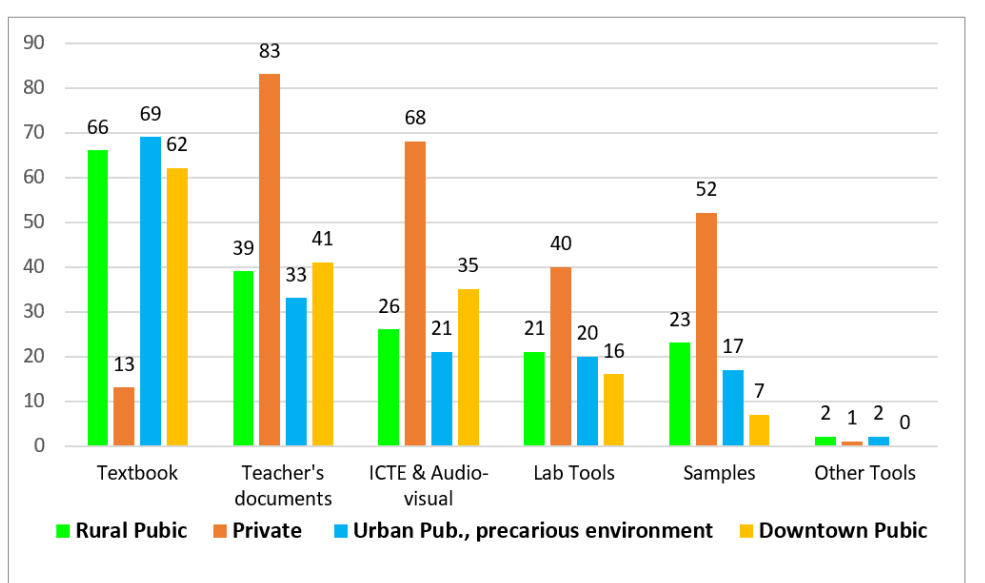

Figure 2. Percentage of different teaching aids often used

Table 7. Correlation between schools and teaching aids used

\begin{tabular}{lcccccccc}
\hline & & Textbook & Teacher's documents & ICTE\&Audio-visual & Lab Tools & Samples & Other Tools \\
\hline \multirow{3}{*}{$\begin{array}{c}\text { Spearman's } \\
\text { rho }\end{array}$} & Schools & Correlation Coefficient & $-.399^{* *}$ & $.305^{* *}$ & $.334^{* *}$ & $.199^{* *}$ & $.194^{* *}$ \\
\cline { 2 - 8 } & Sig. (2-tailed) & .000 & .000 & $.234^{* *}$ \\
\cline { 2 - 8 } & $N$ & 400 & 400 & 400 & .000 & 400 & .000 \\
\hline
\end{tabular}

** Correlation is significant at the 0.01 level (2-tailed).

Table 8. Percentage of students who have scored the average and more in the environmental knowledge test after regular learning sessions (no intervention)

\begin{tabular}{ccccc}
\hline Middle School & Nstudents & $n_{1}$ boys & $n_{2}$ girls & \% Students who obtained the aver-age and more \\
\hline Rural Public & 100 & 56 & 44 & $31 \%$ \\
\hline Urban Pub., precarious environment & 100 & 45 & 55 & $37 \%$ \\
\hline Downtown Public & 100 & 50 & 50 & $38 \%$ \\
\hline Private & 100 & 47 & 53 & $74 \%$ \\
\hline
\end{tabular}

concerning all the teaching aids used. However, there are no significant differences between the three public schools regarding the use of textbooks, teacher's documents and laboratory tools. Admittedly, there was a small significant difference between the downtown public school and the urban precarious school about the use of ICT and audio-visual materials. Also, there is another small significant difference between the downtown public school and the rural public school regarding the use of samples. However, the use of these teaching aids remains significantly low in these public schools in comparison with the private school.

It is important to mention that the various teaching aids used in science course reveal an important pedagogical effort on the part of the teachers, which contributed to a better success in the private school. On the other hand, the excessive use of a single teaching aid (the textbook) has a negative correlation with student's performance (Table 8 and Figure 2). Besides, the number of students per classroom is an important factor in learning achievement (about 25 in the private school and around 40 in the three public middle Schools).

In addition, countless studies have been carried out on the ICT and their indisputable contribution to several levels of learning, such as their contribution to the significant improvement of student performance (Nafidi, Alami, Zaki, El Batri \& Afkar, 2018; Sangra \& González-Sanmamed, 2011; Wendt, Rockinson-Szapkiw \& Cordes,2018). The excessive use of textbook has given rise to several criticisms (Adebayo \& Adigun, 2018; Rodríguez \& Paiva,2017). It can be concluded that the use of the textbook as the only teaching aid in sciences lessons is a good indicator of less effective learning. This is reflected in the poor performance of students (the case of the three public middle Schools studied). In contrast, the diversification of the teaching aids used can constitute a criterion of good student performance (case of the private school and the 3 groups subject of our intervention). This can be seen in the case where the teaching aids are used with active learning methods and a reduced number of students (around 25).

\section{Test of Environmental Knowledge}

Results of the test. Concerning the percentage of students who have scored the average and more in the test of environmental knowledge, it is conspicuous (Table 8) based on the pervasiveness of the private middle school $(74 \%)$. The urban precarious middle school and the urban middle school at downtown were ranked second with the percent- 
age of $37 \%$ and $38 \%$ respectively. Finally, only $31 \%$ of rural public middle school students were able to pass this test.

The analysis of variance (ANOVA, Table 9) showed a very significant difference between the results of the students of the private school and those of the public institutions studied. The same analysis, however, does not reveal any significant discrepancy among the three public schools. Therefore, the ANOVA applied to the participants' grades provides two distinct categories. The first category represents the private school, while the second category puts together all the three public schools. Analysis of the previous results revealed a positive correlation between the use of active learning methods, diversification of teaching aids, and student performance.

Table 9. Analysis of variance (ANOVA) with multiple comparisons of the scores achieved in the four institutions

\begin{tabular}{cccc}
\hline Middle School & N students & $\begin{array}{c}\text { Mean } \\
\text { Difference }\end{array}$ & Sig. \\
\hline \multirow{2}{*}{$\begin{array}{c}\text { Rural Public } \\
\text { Middle } \\
\text { School }\end{array}$} & Urban Pub., precarious environment & -.01000 & .979 \\
\cline { 2 - 4 } & Downtown public M. S. & .01000 & .979 \\
\cline { 2 - 4 } & Private Middle School & $-2.23000^{*}$ & .000 \\
\hline \multirow{2}{*}{$\begin{array}{c}\text { Urban Pub., } \\
\text { precarious } \\
\text { environment }\end{array}$} & Rural Public Middle School & .01000 & .979 \\
\cline { 2 - 4 } & Downtown public M. S. & .02000 & .958 \\
\hline \multirow{2}{*}{$\begin{array}{c}\text { Downtown } \\
\text { Public M. S. }\end{array}$} & Private middle School & $-2.22000^{*}$ & .000 \\
\cline { 2 - 4 } & Urban Pubal public middle School & -.01000 & .979 \\
\cline { 2 - 4 } & Private middle School & $-2.24000^{*}$ & .000 \\
\hline \multirow{2}{*}{$\begin{array}{c}\text { Private } \\
\text { Middle } \\
\text { School }\end{array}$} & Rural public middle School & $2.23000^{*}$ & .000 \\
\cline { 2 - 4 } & Urban Pub., precarious environment & $2.22000^{*}$ & .000 \\
\cline { 2 - 4 } & Private middle School & $2.24000^{*}$ & .000 \\
\hline
\end{tabular}

*. The mean difference is significant at the 0.05 level.

Table 10. The environmental knowledge test done before (pre-test) and after (post-test) the intervention and the regular sessions

\begin{tabular}{|c|c|c|c|c|c|c|c|c|}
\hline & \multirow{3}{*}{$\begin{array}{l}\text { 气ั } \\
\text { 은 }\end{array}$} & \multirow{3}{*}{ 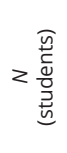 } & \multirow{3}{*}{$\begin{array}{l}\sqrt{n} \\
\widehat{0} \\
\text { en } \\
= \\
=\end{array}$} & \multirow{3}{*}{$\frac{\sqrt[\pi]{\frac{n}{L}}}{\underbrace{N}}$} & \multicolumn{4}{|c|}{$\begin{array}{c}\text { Students Who Have got } \\
\text { Their Average }\end{array}$} \\
\hline & & & & & \multicolumn{2}{|c|}{ Pre-test } & \multicolumn{2}{|c|}{ Post test } \\
\hline & & & & & $\mathrm{n}$ & $\%$ & $\mathrm{n}$ & $\%$ \\
\hline \multirow{4}{*}{$\begin{array}{l}\text { Control sample } \\
\text { (Regular sessions) }\end{array}$} & Gr1 & 40 & 20 & 20 & 0 & 0 & 14 & 35 \\
\hline & Gr2 & 40 & 17 & 23 & 1 & 2.5 & 18 & 45 \\
\hline & Gr3 & $20 *$ & 8 & 12 & 0 & 0 & 5 & 25 \\
\hline & Tot & 100 & 45 & 55 & 1 & 1 & 37 & 37 \\
\hline \multirow{4}{*}{$\begin{array}{l}\text { Experimental } \\
\text { sample } \\
\text { (inter-vention) }\end{array}$} & Gr1 & 21 & 7 & 14 & 1 & 4.76 & 20 & 95 \\
\hline & Gr2 & 20 & 6 & 14 & 0 & 0 & 20 & 100 \\
\hline & Gr3 & 20 & 9 & 11 & 0 & 0 & 20 & 100 \\
\hline & Tot & 61 & 22 & 39 & 1 & 1.64 & 60 & 98 \\
\hline
\end{tabular}

$20^{*}$ : This class contains 41 students who carried out their regular classes, but the knowledge test involved only 20 students who were randomly selected to complete the one hundred students initially set.

Table 10 shows that both control and experimental groups students had almost the same results in the knowledge test before the intervention. That is to say, before learning the test units, the pre-test revealed a percentage of students who were able to get the average less than 5\%. Whereas after the intervention (Post-test), this percentage rose to $37 \%$ for the control groups and $98 \%$ for the experimental groups. To interpret these results, it is necessary to explain the details of the intervention and its positive impact on improving student outcomes.

For Unit 1, students in experimental groups were very involved in handling. They made the microscopic preparations, observed, drawn, compared, and deduced the components of the cell. On the other hand, for the control groups, another teacher did his ordinary work. He made the microscopic preparations and the students simply observed the preparations already made. It seems that the students' active involvement in learning activities has a very positive impact on the acquisition of knowledge and on the appropriation of certain practical skills relating to manipulation.

For unit 2 which is related to chains and food webs, we mainly based our intervention on the exploitation of images of being alive (in the wild) to build food chains. This is with a demonstration on how to write a food chain. During this process, we noticed a very important thing: students make mistakes and cannot easily build food chains from the names of living things. But when these names are replaced by anonymous images of these same living beings, students easily succeed in building a food chain. It can be concluded from this that the amount of information given by the image (visual aids) is greater than that given by the verbal. In the same sense, Felder et al. (2000) stated that most students get much more visual information than verbal information. Thus, Briggs, Stedman and Krasny (2014) suggested that visual methods based on photography lead to deeper understandings.

Concerning unit 3, we used local examples: the deforestation of "Oued Fez" forest and the industrial pollution of "Oued Sebou". By exposing their work, students have discovered by themselves the factors of natural imbalances and their repercussions (extinction of certain species and deterioration of food chains). From the observation of certain significant images related to the factors of ecological imbalances (fires, pollution and overexploitation of the natural resources), students have been invited to draw the eco-responsible behaviors which contribute to the maintenance of the ecological equilibrium from each image. Among the behaviors mentioned are: avoiding pollution of the environment, consuming without wasting natural resources, preserving the forest against fire.

In their study, Saribas et al. (2017) stated that "EE courses should involve presentations, reflections, and discussions on authentic, local, and specific environmental issues" (p. 14). Also, Anderson (2012) pointed out that a more in-depth examination of the local, tangible and concrete aspects of climate change education leads to "individual favourable behaviors that support the march towards climate change mitigation" (cited by Higde et al., 2017, p. 10). Moreover, Tugurian \& Carrier (2017) specify that the child has an environmental identity. This identity can be exploited (according to the author) to improve his environmental behavior and strengthen his interest in the natural sciences. Some authors (Akçali \& Demircioğlu, 2017; Greenberg, 2000) have also emphasized the importance of using the local historic environment in teaching.

For Unit 4, local examples were also used. The students interviewed their families about the species of fish that disappeared from the "Sebou River" and the causes of its extinction. The subject aroused their interest and motivation. However, they discovered the species of fish that disappeared; the shad (Alosa alosa), as well as the type of pollution that caused its extinction (industrial pollution). To discover the second risk threatening water resources (overexploitation), another local example was used; the drying up of Lake "Dayet aoua". Students' responses were supported by pictures. From the analysis of these two examples, students easily arrived at deducing the eco-responsible behavior that must be adopted. These behaviors are the preservation of water against pollution and waste. So, it can be said that the exploitation of local environmental problems in the sciences courses with active methods has resulted in a significant improvement in the acquisition of environmental knowledge. 
Environmental Behavior and Motivation Before and After the Intervention

Here, we measured the impact of our intervention on the student's motivation and readiness to use the acquired knowledge and the improvement of his pro-environmental behaviour. The results are shown in the table below:

Table 11. The use of environmental knowledge (occasionally or often) before and after the intervention

\begin{tabular}{ccccc}
\hline & $\begin{array}{c}\text { The use of declared } \\
\text { knowledge before } \\
\text { the intervention }\end{array}$ & $\begin{array}{c}\text { Intentions of knowl- } \\
\text { edge use after the } \\
\text { intevention }\end{array}$ \\
\hline Eco-responsible behavior & $n / N$ & $\%$ & $n / N$ & $\%$ \\
\hline $\begin{array}{c}\text { The economy in the use of } \\
\text { water }\end{array}$ & $34 / 61$ & $55.73 \%$ & $51 / 61$ & $83.60 \%$ \\
\hline $\begin{array}{c}\text { Preservation of the near en- } \\
\text { vironment against pollution }\end{array}$ & $40 / 61$ & $65.57 \%$ & $54 / 61$ & $88.52 \%$ \\
\hline $\begin{array}{c}\text { Preservation of the forest } \\
\text { against fires }\end{array}$ & $44 / 61$ & $72 \%$ & $57 / 61$ & $93.44 \%$ \\
\hline
\end{tabular}

From the units that were the object of the intervention, we shed light on three main eco-responsible behaviours: the economy in the use of water, the preservation of the close environment against pollution, and the preservation of the forest against fires.

Table 11 shows that our intervention has contributed significantly to improve student motivation and their intention to adopt eco-responsible behaviours in the future. We can deduce that the student's active involvement and engagement in the study of local and tangible environmental problems significantly improves their predisposition and their motivation to adopt pro-environmental behaviours. The very positive impact of addressing local and tangible environmental issues in improving the student's pro-environmental behavior was also emphasized by Saribas et al. (2017); Anderson (2012); Higde et al. (2017); Chanse et al. (2017); Tugurian and Carrier (2017); Jefferson, Ciro, and María Andrea (2017). Although there is a difference between the motivation to adopt a pro-environmental behavior and the actual achievement of this behavior, many authors consider motivation as an internal factor and essential condition for effective learning and also as a precursor of a pro-environmental behaviour (Kollmus \& Agyeman, 2002; Ajzen \& Fishbein, 1980; Linnenbrink, 2006; Moisander, 1998; Fröhlich et al., 2013).

\section{Conclusion}

This study examined, among other things, the effect of an intervention (sciences course) on the acquisition of environmental knowledge and on the predisposition of the student and his motivation to adopt pro-environmental behaviors. The results of the intervention showed that the active involvement of the student in the study of local and tangible environmental problems contributes to significantly improve his acquisition of environmental knowledge related to the sciences syllabus and also his motivation to adopt eco-responsible behavior.

The comparison of the results of the four institutions studied showed that eclecticism is of a great importance. Also, there is a significant positive correlation between the application of active learning methods, the variety of teaching aids, and the degree of mastery of environmental knowledge. It can be said that the use of active learning methods and the diversity of teaching aids used in a science course are indicators of effective learning. This translates into increased student performance. On the other hand, the excessive use of dogmatic methods (student passivity) accompanied by a single teaching aid (the textbook) constitute indicators of less effective learning, especially when it adds to the effect of the high number of students per class (about 40 in our case). Active learning methods emphasize the active involve- ment of students in their learning. Thus, they are widely recommended, whether in general education or especially in environmental education.

Our intervention has also showed that "a picture is worth a thousand words". Hence, the use of images of living beings (as a teaching aid) is highly recommended to facilitate unity learning about food chains. Additionally, the use of images is recommended both to inculcate in mind the factors of natural imbalances and to deduce eco-responsible behaviour.

\section{References}

Acar, D., Tertemiz, N., \& Taşdemir, A. (2018). The Effects of STEM Training on the Academic Achievement of 4th Graders in Science and Mathematics and their Views on STEM Training. International Electronic Journal of Elementary Education, 10(4), 505-513.

Adebayo, O. O., \& Adigun, S. Q. (2018). Impact Of Instructional Aids On Students' Academic Performance In Physics In Secondary Schools In Federal Capital Territory (FCT) Abuja, Nigeria. European Scientific Journal, ESJ, 14(4), 366-376.

Aglan, H. A. \& Ali, S. F. (1996). Hands-On Experiences: An Integral Part of Engineering Curriculum Reform. Journal of Engineering Education, 85(4), 327-330. Retrieved from https://doi.org/10.1002/j.2168-9830.1996. tb00252.x

Ajzen, I. \& Fishbein, M. (1980). Understanding attitudes and predicting social behaviour. behaviour. Prentice-Hall, Englewood Cliffs, NJ.

Akçalı, A. A., \& Demircioğlu, İ. H. (2017). Opinions of pre-service social studies teachers about using historical environment. International Electronic Journal of Elementary Education, 9(1), 39-58.

Alexander, R. J. (2001). Culture and pedagogy: International comparisons in primary education (pp. 391-528). Oxford: Blackwell.

Alexander, R. J. (2006). Towards dialogic teaching: Rethinking classroom talk. Cambridge: Dialogos.

Ameh, I. E., Daniel, B. P., \& Akus, Y. (2007). Research and methods in the Social Sciences. Ankpa: Rowis press.

Anderson, A. (2012). Climate change education for mitigation and adaptation. Journal of Education for Sustainable Development, 6(2), 191-206.

Arénilla, L., Gossot, B., Rolland, M. C., \& Roussel, M. P. (2009). Dictionnaire de pédagogie et de l'éducation [Dictionary of pedagogy and education]. Bordas.

Asokhia, M. O. (2009). Improvisation/teaching aids: Aid to effective teaching of English language. International Education Science, 1(2), 79-85.

Ballantyne, R. \& Packer, J. (2005). Promoting environmentally sustainable attitudes and behaviour through free-choice learning experiences: what is the state of the game?. Environmental Education Research, 11(3), 281-295.

Bonwell, C. C., \& Eison, J. A. (1991). Active Learning: Creating Excitement in the Classroom. 1991 ASHE-ERIC Higher Education Reports. ERIC Clearinghouse on Higher Education, The George Washington University, One Dupont Circle, Suite 630, Washington, DC 200361183. 
Bordallo, I. \& Ginestet, J. P. (2006). Pour une pédagogie du projet [For a project pedagogy]. Hachette éducation.

Braibant, J. M., de Theux, M. N., Aguirre, E., \& Wouters, P. (2002). Sensibilisation des enseignants aux méthodes actives: quel impact et quelle efficacité sur le terrain [Teacher awareness of active methods: what impact and effectiveness on the ground]. AIPU, Louvain-la-Neuve.

Briggs, L. P., Stedman, R. C., \& Krasny, M. E. (2014). Photo-Elicitation Methods in Studies of Children's Sense of Place. Children Youth and Environments, 24(3), 153-172.

Campbell, D. T. \& Stanley, J. C. (1963). Experimental designs for research on teaching. Handbook of research on teaching, 171-246.

Chanse, V., Mohamed, A., Wilson, S., Dalemarre, L., Leisnham, P. T., Rockler, A., ... \& Montas, H. (2017). New approaches to facilitate learning from youth: Exploring the use of Photovoice in identifying local watershed issues. The Journal of Environmental Education, 48(2), 109-120. Retrieved from http://dx.doi. org/10.1080/00958964.2016.1256260

Cheong, I. A. (2005). Educating pre-service teachers for a sustainable environment. Asia-Pacific Journal of Teacher Education, 33(1), 97-110.

Chickering, A. W., \& Gamson, Z. F. (1987). Seven principles for good practice in undergraduate education. AAHE bulletin, 3, 1-6.

Collins, J. W., \& O'Brien, N. P. (2011). The Greenwood dictionary of education. ABC-CLIO.

Conseil Supérieur de l'Éducation, de la Formation et de la Recherche Scientifique (CSEFRS), Maroc. (2018). Une École de Justice Sociale [A School of Social Justice]: Contribution à la réflexion sur le modèle de développement, Maroc, 2018 (Rapport N 9789954-9883-5-0). Retrieved from http://www.csefrs. ma/wp-content/uploads/2018/05/Une-e--ducation-de-justice-sociale-FR.pdf

Cook, T. D., Campbell, D. T., \& Shadish, W. (2002). Experimental and quasi-experimental designs for generalized causal inference. Boston: Houghton Mifflin.

Daluba, N. E. \& Audu, T. A. (2005): Comparing the Academic Performance of Sandwich and Regular Students in Science, Technology and Mathematics Education (STME): Implications for Standards. In J. B, Omonu, T. A. Audu, P. P. Agashi (Eds): Sandwich / Part-Time Programme and Science Technology and Mathematics Education in Nigeria (47 - 52). Anyigba: Sam Artrade Publisher.

Declaration, R. (1992). Rio declaration on environment and development. Retrieved from http://www.unesco. org/education/pdf/RIO_E.PDF

Directorate of Curricula (2009). Morocco. Retrieved from http://www.etudiantdumaroc.com/tawjihat-tarbawia-college/svt.pdf

Do, K. L. (2003). L'exploration du dialogue de Bohm comme approche d'apprentissage: une recherche collaborative [Exploring Bohm's Dialogue as a Learning Approach: Collaborative Research] (Doctoral dissertation, Université Laval). Retrieved from https://corpus.ulaval.ca/jspui/bitstream/20.500.11794/17791/1/20640.pdf
Dori, Y. J. \& Tal, R. T. (2000). Formal and informal collaborative projects: Engaging in industry with environmental awareness. Science Education, 84(1), 95-113.

Dufresne, R. J., Gerace, W. J., Leonard, W. J., Mestre, J. P., \& Wenk, L. (1996). Classtalk: A classroom communication system for active learning. Journal of computing in higher education, 7(2), 3-47.

Ekeyi, D. N. (2013). Effect of demonstration method of teaching on students' achievement in agricultural science. World Journal of Education, 3(6), 1-7.

Erdogan, M. (2009). Fifth grade students' environmental literacy and the factors affecting the students' environmentally responsible behaviors (Unpublished PhD Dissertation). Ankara: Middle East Technical University.

Erdosne Toth, E., Klahr, D., \& Chen, Z. (2000). Bridging research and practice: A cognitively based classroom intervention for teaching experimentation skills to elementary school children. Cognition and instruction, 18(4), 423-459.

Erten, S. (2005). Okul öncesi öğretmen adaylarında çevre dostu davranışların araştırılması. Hacettepe Üniversitesi Eğitim Fakültesi Dergisi, 28, 91-100.

Esa, N. (2010). Environmental knowledge, attitude and practices of student teachers. International Research in Geographical and Environmental Education, 19(1), 39-50.

Falk, A. \& Heckman, J. J. (2009). Lab experiments are a major source of knowledge in the social sciences. Science, 326(5952), 535-538.

Felder, R. M., Woods, D. R., Stice, J. E., \& Rugarcia, A. (2000). The future of engineering education II. Teaching methods that work. Chemical Engineering Education, 34(1), 26-39.

Fröhlich, G., Sellmann, D., \& Bogner, F. X. (2013). The influence of situational emotions on the intention for sustainable consumer behaviour in a student-centred intervention. Environmental Education Research, 19(6), 747-764.

Genc, M. (2015). The project-based learning approach in environmental education. International Research in Geographical and Environmental Education, 24(2), 105-117.

Goldberg, J. R., \& Nagurka, M. L. (2012, October). Enhancing the engineering curriculum: Defining discovery learning at Marquette University. In Frontiers in Education Conference (FIE), 2012 (pp. 1-6). IEEE.

Gottlieba, D., Vigoda-Gadota, E., \& Haim, A. (2013). Encouraging ecological behaviours among students by using the ecological footprint as an educational tool: A quasi-experimental design in a public high school in the city of Haifa. Environmental Education Research, 19(6), 844-863.

Greenberg, R. M. (Ed.). (2000). Creative teaching with historic places. Washington, DC: National Park Service

Hartmann, W., Näf, M., \& Reichert, R. (2011). Pédagogie de projet [Project pedagogy]. Enseigner l'informatique, 105-111. 
Higde, E., Oztekin, C., \& Sahin, E. (2017). Turkish pre-service science teachers' awareness, beliefs, values, and behaviours pertinent to climate change. International Research in Geographical and Environmental Education, 26(3), 253-263. Retrieved from https://doi.org/10 $.1080 / 10382046.2017 .1330040$

Huber, M. (2005). Apprendre en projets: la pédagogie du projet-élèves [Learning in projects: pedagogy of the student project]. Chronique sociale.

Jefferson, G. M., Ciro, P. M., \& María Andrea, M. S. (2017). Environmental education and the Bogotá River: an intervention to be carried out in Cundinamarca (CoIombia). International Research in Geographical and Environmental Education, 26(4), 281-296.

Johnson, D. W., Johnson, R. T., \& Smith, K. A. (1998). Active learning: Cooperation in the middle School classroom. Interaction Book Company, 7208 Cornelia Drive, Edina, MN 55435.

Karataş, A. (2011). Çevre bilincinin geliştirilmesinde doğa tarihi müzelerinin rolü [The role of natural history museums in the development of environmental awareness]. Akademik Bakış Dergisi, 27, 1-15.

Karpudewan, M. \& Mohd Ali Khan, N. S. (2017). Experiential-based climate change education: fostering students' knowledge and motivation towards the environment. International Research in Geographical and Environmental Education, 1-16.

Keles, O., Uzun, N., \& Varnaci-Uzun, F. (2010). The change of teacher candidates' environmental consciousness, attitude, thought and behaviors with nature training project and the assessment of its permanence. Electronic Journal of Social Sciences, 9(32), 384-401.

Kollmuss, A., \& Agyeman, J. (2002). Mind the gap: why do people act environmentally and what are the barriers to pro-environmental behavior?. Environmental education research, 8(3), 239-260. Retrieved from http:// dx.doi.org/10.1080/13504620220145401

Kresta, S. M. (1998). Hands-on Demonstrations: An Alternative to Full Scale Lab Experiments. Journal of Engineering Education, 87(1), 7-9.

Leeming, F. C., Porter, B. E., Dwyer, W. O., Cobern, M. K., \& Oliver, D. P. (1997). Effects of participation in class activities on children's environmental attitudes and knowledge. The Journal of Environmental Education, 28(2), 33-42.

Linnenbrink, E. A. (2006). Emotion research in education: Theoretical and methodological perspectives on the integration of affect, motivation, and cognition. Educational Psychology Review, 18(4), 307-314.

Makki, M. H., Abd-El-Khalick, F., \& BouJaoude, S. (2003). Lebanese secondary school students' environmental knowledge and attitudes. Environmental Education Research, 9(1), 21-33.

Mayer, R. E. (2004). Should there be a three-strikes rule against pure discovery learning?. American psychologist, 59(1), 14.

Mikerova, G., Sergeeva, B., Mardirosova, G., Kazantseva, V., \& Karpenko, A. (2018). Learning Environment Affecting Primary School Student's Mental Development and Interest. International Electronic Journal of Elementary Education, 10(4), 407-412.

Miser, R. (2010). Çevre eğitimi. Ankara Üniversitesi Eğitim Bilimleri Fakültesi Mezunları Derneği Yayınları, Ankara.
Moisander, J. (1998, March). Motivation for ecologically oriented consumer behaviour. In 2nd European Science Foundation Workshop. Lancaster ESF-Term programme: Consumption, Everyday Life and Sustainability.

Muhonen, H., Rasku-Puttonen, H., Pakarinen, E., Poikkeus, A. M., \& Lerkkanen, M. K. (2016). Scaffolding through dialogic teaching in early school classrooms. Teaching and teacher education, 55, 143-154.

Nafidi, Y., Alami, A., Zaki, M., El Batri, B., \& Afkar, H. (2018). Impacts of the Use of a Digital Simulation in Learning Earth Sciences (the Case of Relative Dating in High School). Journal of Turkish Science Education (TUSED), 15(1).

Norman, G. R. \& Schmidt, H. G. (2000). Effectiveness of problem-based learning curricula: Theory, practice and paper darts. Medical education, 34(9), 721-728.

Norton, S., McRobbie, C. J., \& Cooper, T. J. (2000). Exploring secondary mathematics teachers' reasons for not using computers in their teaching: Five case studies. Journal of research on computing in education, 33(1), 87-109.

Prince, M. (2004). Does active learning work? A review of the research. Journal of engineering education, 93(3), 223231.

Prince, M. J., \& Felder, R. M. (2006). Inductive teaching and learning methods: Definitions, comparisons, and research bases. Journal of engineering education, 95(2), 123-138.

Rodríguez, J. R., \& Paiva, M. D. (2017). Learning difficulties in textbooks and didactic materials in Portugal. Educação e Pesquisa, 43(3), 765-784.

Samur, A. Ö. (2018). A Comparison of 60-72 Month Old Children's Environmental Awareness and Attitudes: TEMA Kids Program. International Electronic Journal of Elementary Education, 10(4), 413-419.

Sangra, A., \& González-Sanmamed, M. (2011). The Role of Information and Communication Technologies in Improving Teaching and Learning Processes in Primary and Secondary Schools. Journal of Asynchronous Learning Networks, 15(4), 47-59.

Saribas, D., Kucuk, Z. D., \& Ertepinar, H. (2017). Implementation of an environmental education course to improve pre-service elementary teachers' environmental literacy and self-efficacy beliefs. International Research in Geographical and Environmental Education, 26(4), 311-326. Retrieved from https://doi.org/10.10 80/10382046.2016.1262512

Sauvé, L. (1999). Un «patrimoine» de recherche en construction [A "heritage" of research in construction]. Éducation relative à l'environnement: Regards-Recherches-Réflexions, 1, 13-40. Retrieved from https://archipel.uqam.ca/7101/1/EREV01_II_013.pdf

Silberman, M. (1996). Active Learning: 101 Strategies To Teach Any Subject. Prentice-Hall, PO Box 11071, Des Moines, IA 50336-1071.

Tugurian, L. P. \& Carrier, S. J. (2017). Children's environmental identity and the elementary science classroom. The Journal of Environmental Education, 48(3), 143153. Retrieved from http://dx.doi.org/10.1080/0095 8964.2016.1191415 
Tuncer*, G., Ertepinar, H., Tekkaya, C., \& Sungur, S. (2005). Environmental attitudes of young people in Turkey: Effects of school type and gender. Environmental Education Research, 11(2), 215-233.

Tuncer, G., Sungur, S., Tekkaya, C., \& Ertepinar, H. (2007) A comparative study on pre-service teachers' and elementary students' attitudes towards the environment. International Research in Geographical \& Environmental Education, 16(2), 188-198. Retrieved from https://doi.org/10.2167/irgee217.0

UNESCO (2016). Global Education Monitoring Report. Education for people and planet: Creating susttainable futurs for all. Retrieved from http://unesdoc.unesco.org/images/0024/002457/245752e.pdf

Van Winkle, R., Davis, W., \& Larwood, L. (2002). Active teaching-active learning teaching techniques and tools.

Wallace, S. (2015). A dictionary of education. OUP Oxford.

Wendt, J. L., Rockinson-Szapkiw, A., \& Cordes, M. (2018). Examining the influence of a STEM certification model on female, minority science outcomes. The Journal of Educational Research, 111(6), 666-677.

William R.. Shadish, Cook, T. D., \& Campbell, D. T. (2002). Experimental and quasi-experimental designs for generalized causal inference. Wadsworth Cengage learning. 